MS

Editions

BOLETIN LATINOAMERICANO Y DEL CARIBE DE PLANTAS MEDICINALES Y AROMÁTICAS

19 (6): 527 - 541 (2020)

(C) / ISSN 07177917 / www.blacpma.ms-editions.cl

\title{
Revisión / Review \\ Lindera aggregata (Sims) Kosterm: Review on phytochemistry and biological activities
}

[Lindera agreggata (Sims) Kosterm: revisión de su fitoquímica y actividades biológicas]

Wan Mohd Nuzul Hakimi Wan Salleh

Department of Chemistry, Faculty of Science and Mathematics, Universiti Pendidikan Sultan Idris (UPSI), 35900 Tanjung Malim, Perak, Malaysia

Contactos | Contacts: Wan Mohd Nuzul Hakimi Wan SALLEH - E-mail address: wmnhakimi@ fsmt.upsi.edu.my

\begin{abstract}
The genus Lindera consists of approximately 100 species that are widely distributed in tropical and subtropical areas throughout the world. Most Lindera plants, particularly Lindera aggregata is a well-known traditional Chinese medicine that has important medicinal value and health benefits. Contemporary chemical and pharmacological studies have shown that L. aggregata are a source of structurally diverse molecules having pharmacological potential. In an effort to promote research on L. aggregata and develop therapeutic and pharmacological products, this review describes the structural diversity of its components and pharmacological and biological significance of L. aggregata. This review is based on a literature analysis of scientific journals from electronic sources, such as Science Direct, PubMed, Google Scholar, Scopus and Web of Science. Thus, with the growing interest in traditional medicine and botanical drugs worldwide, $L$. aggregata will increasingly capture chemists' and pharmacologists' attention because they produce diverse and structurally novel compounds having pharmacological significance.
\end{abstract}

Keywords: Lauraceae; Lindera aggregata; Phytochemistry; Sesquiterpenoid; Alkaloid; Phenolic.

Resumen: El género Lindera consta de aproximadamente 100 especies que están ampliamente distribuidas en áreas tropicales y subtropicales en todo el mundo. La mayoría de las plantas de Lindera, particularmente Lindera aggregata, es parte conocida de la medicina tradicional china con un importante valor medicinal y beneficios para la salud. Estudios químicos y farmacológicos contemporáneos han demostrado que L. aggregata es una fuente de moléculas estructuralmente diversas que con potencial farmacológico. En un esfuerzo por promover la investigación sobre L. aggregata y desarrollar productos terapéuticos y farmacológicos, esta revisión describe la diversidad estructural de sus componentes y la importancia farmacológica y biológica de L. aggregata. Esta revisión se basa en un análisis de literatura de revistas científicas de fuentes electrónicas, como Science Direct, PubMed, Google Scholar, Scopus y Web of Science. Por lo tanto, con el creciente interés en la medicina tradicional y las drogas botánicas en todo el mundo, L. aggregata captará cada vez más la atención de los químicos y farmacólogos debido a que producen compuestos diversos y estructuralmente novedosos que tienen importancia farmacológica.

Palabras clave: Lauraceae; Lindera aggregata; Fitoquímica; Sesquiterpenoide; Alcaloide; Fenólico

Recibido | Received: April 19, 2020

Aceptado | Accepted: May 8, 2020

Aceptado en versión corregida | Accepted in revised form: May 12, 2020

Publicado en línea | Published online: November 30, 2020

Este artículo puede ser citado como / This article must be cited as: WMNHW Salleh. 2020. Lindera aggregata (Sims) Kosterm: Review on phytochemistry and biological activities. Bol Latinoam Caribe Plant Med Aromat 19 (6): 527 - 541. https://doi.org/10.37360/blacpma.20.19.6.37 


\section{INTRODUCTION}

For centuries, botanical remedies have been used for human disease management because plants contain multitude of novel components of diverse therapeutic value. The Lauraceae family is by far the largest family of the order Laurales with about 50 genera and over 2000 species distributed throughout tropical to subtropical latitudes especially in Southeast Asia and tropical America (Van der Werff \& Richter, 1996; Salleh et al., 2015). Most of the plants of this family and particularly genus Lindera are of great interest to pharmacists as preliminary pharmacological studies proved that these plants have the efficient medicinal potential for the treatment of broad-spectrum health disorders (Cao et al., 2016). The genus Lindera consists of approximately 100 species that are widely distributed in tropical, subtropical, and temperate zones of Asia and Midwestern America (Tsui, 1987). Lindera plants are rich in essential oils and are used for producing spices, fragrances, and building timber. It also reported that the plants are appropriate for manufacturing soaps and lubricants (Flora of China Editorial Committee, 2010).

Lindera aggregata (Sims.) Kosterm. (Lauraceae) (Figure No. 1) is an important medicinal plant, widely distributed in China, Japan, Taiwan, and Southeast Asia (Li, 1984). In China, it is locally known as $W u Y a o$, while in Japan known as Uyaku. L. aggregata is an evergreen shrub or small tree that is widely distributed and common across the eastern moist subtropical evergreen broadleaved forests (Wang et al., 2007). Some isolated outposts have also been reported from Vietnam and the Philippines and the species is sometimes cultivated outside its native range. The plant grows on sunny mountain slopes, in sparse forests and thickets at elevations between 200 and $1,000 \mathrm{~m}$. It is dioecious, produces entomophilous flowers and fleshy drupes that are putatively dispersed by birds (Hirayama et al., 2004). The Flora of China and The Plant List recognize two varieties which are L. aggregata var. hemsleyana (Diels) S.S.Ying and L. aggregata var. playfairii (Hemsl.) H.B. Cui (The Flora of China, 2010; The Plant List, 2010). Previous phytochemical investigations revealed that sesquiterpenoids are the main secondary metabolites isolated from this plant.

Due to its diverse applications, wide attention has been paid by scientific communities and plenty of investigations on bioactive constituents and pharmacological activities have been conducted. At this time, we summarize research findings on phytochemistry and their pharmacological activities. This highlights the current status and likely future directions that will provide a representative overview of this medicinal plant. The scientific databases: Google Scholar, Web of Science, PubMed, and Scopus were utilized to gather all relevant information from literature articles.

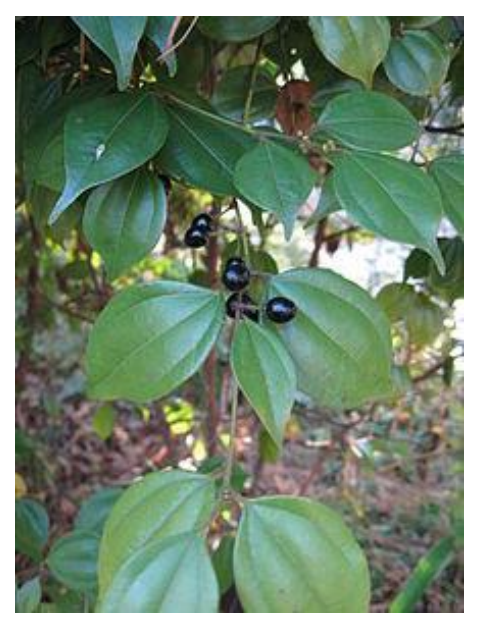

Figure No. 1

Lindera aggregata (Sims.) Kosterm.

\section{Traditional uses}

There is a long history of using L. aggregata in traditional Chinese medicine for the treatment of various diseases. L. aggregata extracts is usually used for treating urinary system diseases such as enuresis and urinary stones. Besides, it has pronounced effects on chronic gastritis and rheumatoid arthritis (Zhang \& Wang, 2000). In addition, mashed leaves of $L$. aggregata are beneficial for treating mastitis, acute cellulitis, and carbuncles (Chou et al., 2000). Fresh cut leaves of $L$. aggregata stir-fried in rice wine show the therapeutic effect on rheumatoid arthritis. In addition, $L$. aggregata extracts are used in Japan to treat stroke and cholera (Han et al., 2008).

\section{PHYTOCHEMISTRY}

A review of the literature revealed that few phytochemical studies have been carried out on $L$. aggregata. The studies have reported the presence of several classes of secondary metabolites including sesquiterpenoids, amides, alkaloids, flavonoids, procyanidins, lignans, benzenoids, butenolides, phenolics, and essential oils. The isolated phytochemicals are tabulated in Table No. 1. 
Table No. 1

Phytochemicals isolated from Lindera aggregata

\begin{tabular}{|c|c|c|c|}
\hline No & Constituents & Parts & References \\
\hline & SESQUITERPENOIDS & & \\
\hline 1 & Aggreganoid A & Roots & Liu et al., 2009a \\
\hline 2 & Aggreganoid B & Roots & Liu et al., 2009a \\
\hline 3 & Aggreganoid C & Roots & Liu et al., 2009a \\
\hline 4 & Aggreganoid D & Roots & Liu et al., 2009a \\
\hline 5 & Aggreganoid E & Roots & Liu et al., 2009a \\
\hline 6 & Aggreganoid $\mathrm{F}$ & Roots & Liu et al., 2009a \\
\hline 7 & Linderalide A & Roots & Liu et al., 2009b \\
\hline 8 & Linderalide B & Roots & Liu et al., 2009b \\
\hline 9 & Linderalide C & Roots & Liu et al., 2009b \\
\hline 10 & Linderalide D & Roots & Liu et al., 2009b \\
\hline 11 & Linderanlide A & Root tubers & Qiang et al., 2011 \\
\hline 12 & Linderanlide B & Root tubers & Qiang et al., 2011 \\
\hline 13 & Linderanlide $\mathrm{C}$ & Root tubers & Qiang et al., 2011 \\
\hline 14 & Linderanlide D & Root tubers & Qiang et al., 2011 \\
\hline 15 & Linderanlide E & Root tubers & Qiang et al., 2011 \\
\hline 16 & Linderanlide F & Root tubers & Qiang et al., 2011 \\
\hline 17 & Linderanine A & Root tubers & Qiang et al., 2011 \\
\hline 18 & Linderanine B & Root tubers & Qiang et al., 2011 \\
\hline 19 & Linderanine $\mathrm{C}$ & Root tubers & Qiang et al., 2011 \\
\hline 20 & $(+)$-Linderadine & Root tubers & Qiang et al., 2011 \\
\hline 21 & ent-4(15)-Eudesmene-1 $\beta, 6 \alpha$-diol & Root tubers & Qiang et al., 2011 \\
\hline 22 & Dehydrocostuslactone & Root tubers & Qiang et al., 2011 \\
\hline 23 & Linderagalactone A & Root tubers & Gan et al., 2009a \\
\hline 24 & Linderagalactone $\mathrm{B}$ & Root tubers & Gan et al., 2009a \\
\hline \multirow[t]{2}{*}{25} & Linderagalactone $\mathrm{C}$ & Root tubers & Gan et al., 2009a \\
\hline & & Roots & Wu et al., 2010 \\
\hline \multirow[t]{2}{*}{26} & Linderagalactone D & Root tubers & Gan et al., 2009a \\
\hline & & Roots & Wu et al., 2010 \\
\hline 27 & Linderagalactone E & Root tubers & Gan et al., 2009a \\
\hline 28 & 3-Eudesmene-1 $\beta, 11$-diol & Root tubers & Gan et al., 2009a \\
\hline \multirow[t]{5}{*}{29} & Hydroxylindestenolide & Root tubers & Gan et al., 2009a \\
\hline & & Leaves & Zhang et al., 2001 \\
\hline & & Root tubers & Qiang et al., 2011 \\
\hline & & Roots & Wu et al., 2010 \\
\hline & & Roots & Ma et al., 2015 \\
\hline 30 & Dehydrolindestrenolide & Leaves & Zhang et al., 2001 \\
\hline 31 & Strychnistenolide & Root tubers & Gan et al., 2009a \\
\hline 32 & Hydroxyisogermafurenolide & Root tubers & Gan et al., 2009a \\
\hline 33 & Atractylenolide III & Root tubers & Gan et al., 2009a \\
\hline \multirow[t]{4}{*}{34} & Linderane & Root tubers & Gan et al., 2009a \\
\hline & & Roots & Cheng et al., 2007 \\
\hline & & Roots & Wu et al., 2010 \\
\hline & & Root tubers & Qiang et al., 2011 \\
\hline \multirow[t]{2}{*}{35} & Neolinderalactone & Root tubers & Gan et al., 2009a \\
\hline & & Roots & Wu et al., 2010 \\
\hline 36 & Neolindenenonelactone & Roots & Cheng et al., 2007 \\
\hline 37 & Isolinderalactone & Roots & Cheng et al., 2007 \\
\hline \multirow[t]{2}{*}{38} & Linderalactone & Roots & Cheng et al., 2007 \\
\hline & & Root tubers & Gan et al., 2009a \\
\hline
\end{tabular}




\begin{tabular}{|c|c|c|c|}
\hline & & Root tubers & Qiang et al., 2011 \\
\hline & & Leaves & Zhang et al., 2001 \\
\hline 39 & 8-Hydroxylindestenolide & Roots & Cheng et al., 2007 \\
\hline \multirow{2}{*}{40} & bi-Linderone & Roots & Wang et al., 2010a \\
\hline & & Roots & Chen et al., 2018 \\
\hline 41 & epi-bi-linderone & Roots & Chen et al., 2018 \\
\hline \multirow[t]{2}{*}{42} & $( \pm)$-Linderaspirone A & Roots & Wang et al., 2010b \\
\hline & & Roots & Chen et al., 2018 \\
\hline 43 & $( \pm)$-Lindepentone A & Roots & Chen et al., 2018 \\
\hline 44 & Lindoxepines A & Roots & Chen et al., 2018 \\
\hline 45 & Lindoxepines B & Roots & Chen et al., 2018 \\
\hline 46 & (+)-Demethoxy-epi-bi-linderone & Roots & Chen et al., 2018 \\
\hline 47 & (-)-Demethoxy-epi-bi-linderone & Roots & Chen et al., 2018 \\
\hline 48 & Methyllinderone & Roots & Chen et al., 2018 \\
\hline \multirow[t]{2}{*}{49} & Methyllucidone & Roots & Chen et al., 2018 \\
\hline & $\begin{array}{l}\text { AMIDES AND ALKALOIDS } \\
(+) \text {-Norboldine acetate }\end{array}$ & Roots & Gan et al., 2009b \\
\hline \multirow[t]{2}{*}{51} & (+)-Norboldine & Roots & Gan et al., 2009b \\
\hline & & Roots & Han et al., 2008 \\
\hline \multirow[t]{5}{*}{52} & (+)-Boldine & Roots & Gan et al., 2009b \\
\hline & & Roots & Chou et al., 2005 \\
\hline & & Roots & Han et al., 2008 \\
\hline & & Roots & Ma et al., 2015 \\
\hline & & Roots & Yang et al., 2020 \\
\hline \multirow[t]{2}{*}{53} & (+)-Laurotetanine & Roots & Gan et al., 2009b \\
\hline & & Roots & Yang et al., 2020 \\
\hline \multirow[t]{3}{*}{54} & $(+)$-N-methyllaurotetanine & Roots & Gan et al., 2009b \\
\hline & & Roots & Ma et al., 2015 \\
\hline & & Roots & Yang et al., 2020 \\
\hline \multirow[t]{5}{*}{55} & $(+)$-Reticuline & Roots & Gan et al., 2009b \\
\hline & & Roots & Chou et al., 2005 \\
\hline & & Roots & Gan et al., 2008 \\
\hline & & Roots & Han et al., 2008 \\
\hline & & Roots & Yang et al., 2020 \\
\hline \multirow[t]{2}{*}{56} & (-)-Pronuciferine & Roots & Gan et al., 2009b \\
\hline & & Roots & Chou et al., 2005 \\
\hline \multirow[t]{3}{*}{57} & Pallidine & Roots & Gan et al., 2009b \\
\hline & & Roots & Chou et al., 2005 \\
\hline & & Roots & Gan et al., 2008 \\
\hline 58 & Linderaline & Roots & Chou et al., 2005 \\
\hline 59 & Protosinomenine & Roots & Chou et al., 2005 \\
\hline 60 & Laudanosoline 3',4'-dimethyl ether & Roots & Chou et al., 2005 \\
\hline \multirow[t]{2}{*}{61} & Norisoboldine & Roots & Chou et al., 2005 \\
\hline & & Roots & Yang et al., 2020 \\
\hline \multirow[t]{3}{*}{62} & Linderagatine & Roots & Gan et al., 2008 \\
\hline & & Roots & Han et al., 2008 \\
\hline & & Roots & Yang et al., 2020 \\
\hline \multirow[t]{2}{*}{63} & Linderaggrine $\mathrm{A}$ & Roots & Kuo et al., 2014 \\
\hline & & Roots & Ma et al., 2015 \\
\hline 64 & N-trans-feruloyltyramine & Roots & Ma et al., 2015 \\
\hline 65 & N-cis-feruloyltyramine & Roots & Ma et al., 2015 \\
\hline 66 & N-trans-feruloylmethoxytyramine & Roots & Ma et al., 2015 \\
\hline 67 & $(+)$-Isoboldine & Roots & Ma et al., 2015 \\
\hline
\end{tabular}




\begin{tabular}{|c|c|c|c|}
\hline & & Roots & Yang et al., 2020 \\
\hline 68 & Thalifoline & Roots & Ma et al., 2015 \\
\hline 69 & Northalifoline & Roots & Ma et al., 2015 \\
\hline 70 & Yuzirine & Roots & Ma et al., 2015 \\
\hline 71 & (1'S)-12'-Hydroxyl-linderegatine & Roots & Yang et al., 2020 \\
\hline 72 & (1S)-5'-O-p-Hydroxybenzoyl norreticuline & Roots & Yang et al., 2020 \\
\hline 73 & $\left(1 \mathrm{R}, 1^{\prime} \mathrm{R}\right)-11,11^{\prime}$-Biscoclaurine & Roots & Yang et al., 2020 \\
\hline 74 & Costaricine & Roots & Yang et al., 2020 \\
\hline 75 & Actinodaphnine & Roots & Yang et al., 2020 \\
\hline 76 & Laurolitsine & Roots & Yang et al., 2020 \\
\hline 77 & Norjuziphine & Roots & Yang et al., 2020 \\
\hline 78 & Reticuline n-oxide & Roots & Yang et al., 2020 \\
\hline 79 & Boldine n-oxide & Roots & Yang et al., 2020 \\
\hline 80 & N-methyllaurotetanine n-oxide & Roots & Yang et al., 2020 \\
\hline 81 & Salutaridine n-oxide & Roots & Yang et al., 2020 \\
\hline 82 & Lindoldhamine & Roots & Yang et al., 2020 \\
\hline 83 & Secolaurolitsine & Roots & Yang et al., 2020 \\
\hline \multirow[t]{2}{*}{84} & Secoboldine & Roots & Yang et al., 2020 \\
\hline & FLAVONOIDS & & \\
\hline 85 & Quercetin & Leaves & Xiao et al., 2011 \\
\hline 86 & Quercetin-3-O- $\alpha$-D-arabinofuranoside & Leaves & Xiao et al., 2011 \\
\hline 87 & Quercetin-3-O- $\alpha$-D-glucopyranoside & Leaves & Xiao et al., 2011 \\
\hline 88 & Quercetin-3-O- $\alpha$-L-rhamnopyranoside & Leaves & Han et al., 2008 \\
\hline \multirow[t]{2}{*}{89} & Quercitrin & Leaves & Xiao et al., 2011 \\
\hline & & & Xu et al., 2017 \\
\hline 90 & Kaempferol & Leaves & Xiao et al., 2011 \\
\hline 91 & Kaempferol-3-O-L-rhamnoside & Leaves & Xiao et al., 2011 \\
\hline 92 & Kaempferol-3-O-D-glucopyranoside & Leaves & Xiao et al., 2011 \\
\hline \multirow[t]{2}{*}{93} & Dihydrokaempferol-3-O-L-rhamnoside & Leaves & Xiao et al., 2011 \\
\hline & PROCYANIDINS & & \\
\hline 94 & Procyanidin B1 & Leaves & Zhang et al., 2003 \\
\hline 95 & Cinnamtanin B1 & Leaves & Zhang et al., 2003 \\
\hline 96 & Cinnamtannin B2 & Leaves & Zhang et al., 2003 \\
\hline & LIGNANS & & \\
\hline 97 & 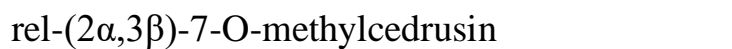 & Roots & Ma et al., 2015 \\
\hline 98 & (-)-Lyoniresinol & Roots & Ma et al., 2015 \\
\hline \multirow[t]{2}{*}{99} & Evofolin B & Roots & Ma et al., 2015 \\
\hline & BENZENOIDS & & \\
\hline 100 & Linderagatin A & Roots & Ma et al., 2015 \\
\hline \multirow[t]{2}{*}{101} & Linderagatin B & Roots & Ma et al., 2015 \\
\hline & BUTENOLIDE & & \\
\hline \multirow[t]{2}{*}{102} & Secoaggregatalactone A & Leaves & Lin et al., 2007 \\
\hline & PHENOLICS & & \\
\hline 103 & 3-Hydroxy-1-(4-hydroxyphenyl)propan-1-one & Roots & Ma et al., 2015 \\
\hline 104 & p-Hydroxybenzoic acid & Roots & Ma et al., 2015 \\
\hline 105 & 4-Hydroxy-3-methoxy acetophenone & Roots & Ma et al., 2015 \\
\hline 106 & Methyl 3,5-dimethoxy-4-hydroxybenzoate & Roots & Ma et al., 2015 \\
\hline 107 & Vanillic acid & Roots & Ma et al., 2015 \\
\hline 108 & Tyrosol & Roots & Ma et al., 2015 \\
\hline 109 & 2-(4-Hydroxy-3-methoxyphenyl)-ethanol & Roots & Ma et al., 2015 \\
\hline 110 & 2-(4-Hydroxy-3,5-dimethoxyphenol)-ethanol & Roots & Ma et al., 2015 \\
\hline 111 & 2,6-Dimethoxy-p-benzoquinone & Roots & Ma et al., 2015 \\
\hline
\end{tabular}




\begin{tabular}{|c|c|c|c|}
\hline 112 & 6'-O-Vanilloyltachioside & Roots & Ma et al., 2015 \\
\hline & OTHERS & & \\
\hline 113 & (-)-Boscialin & Roots & Ma et al., 2015 \\
\hline 114 & Methyl dihydrophaseate & Roots & Ma et al., 2015 \\
\hline
\end{tabular}

\section{Sesquiterpenoids}

A total of forty-nine sesquiterpenoids (1-49), including dimeric and trimeric sesquiterpenoids have been reported phytochemically from L. aggregata. The chemical structures are shown in Figure No. 2. Liu et al. (2009a) were successfully isolated and characterized six unprecedented sesquiterpenoid trimmers and dimers, aggreganoids A-F (1-6) from the ethanolic extract of the roots of L. aggregata. These compounds represent a new class of oligomeric sesquiterpenoids featuring the connection between different or identical sesquiterpenoid monomers via a carbon bridge. The new linkage pattern of these compounds is not only crucial for the chemical diversity and biosynthesis of oligomeric sesquiterpenoids, but also the chemotaxonomic studies on genus Lindera. In the same year, the authors also managed to isolate four disesquiterpenoid-geranylbenzofuranone conjugates, linderalides A-D (7-10) from the same part. These compounds represent the first examples of disesquiterpenoid-geranylbenzofuranone hybrids directly linked by two $\mathrm{C}-\mathrm{C}$ bonds. Another compound was linderalide D (10), which bears an unprecedented carbon skeleton featuring an unusual linearly 6/6/5/6/6 pentacyclic ring system fused by a sesquiterpenoid unit and a geranylbenzofuranone moiety.

In another study, Chen et al. (2018) were reported a novel skeleton of 3,5-dioxocyclopent-1enecarboxylate, known as ( \pm )-lindepentone A (43), together with an unprecedented oxepine-2,5-dione derivative skeleton, lindoxepines A-B (44-45). The authors also suggest that compound (44-45) might be the key intermediates for the synthesis of Lindera cyclopentenediones. Besides, Qiang et al. (2011) have successfully isolated six new sesquiterpenoids, known as linderanlide A-F (11-16) from the root tubers part. Linderanlide A (11) is a C-8 epimer of linderanine C (19). Meanwhile, Wang et al. (2010a) reported the isolation of a racemate, bi-linderone (40) from the roots part. The compound represents the first member of an unprecedented class of spirocyclopentene diones. Although it shares its structural features with the cyclopentenedione derivative methyl-linderone (48), it has a backbone with 34 carbon atoms that includes a unique spiro ring, which is unprecedented in the field of natural products. In the meantime, the authors also managed to isolate a pair of natural windmill-shaped enantiomers, known as ( \pm )-linderaspirone A (42). The biogenetic route to linderaspirone A (42) was proposed to be a formation by a [4+4] cycloaddition from the monomer methyl linderone (48). Furthermore, Gan et al. (2009a) were reported the identification of five new sesquiterpene lactones, named as linderagalactones A-E (23-27) from the roots part. In addition, Cheng et al. (2007) were managed to characterize a new sesquiterpene, neolindenenonelactone (35), along with linderane (34), isolinderalactone (37), linderalactone (38), and 8-hydroxylindestenolide (39).

\section{Amides and alkaloids}

Thirty-five alkaloids including amides (50-84) were successfully identified from the roots of $L$. aggregata. The chemical structures are shown in Figure No. 3. Gan et al. (2009b) was reported the isolation of new alkaloid, (+)-norboldine acetate $(\mathbf{5 0})$ together with $(+)$-norboldine $(\mathbf{5 1}),(+)$-boldine $(\mathbf{5 2})$, $(+)$-laurotetanine $\quad(\mathbf{5 3}), \quad(+)-N$-methyllaurotetanine (54), (+)-reticuline (55), (-)-pronuciferine (56), and pallidine (57) from the roots of L. aggregata. A year before, the authors also reported a novel bisbenzylisoquinoline alkaloid, linderegatine (62), as well as two known isoquinoline alkaloids reticuline (55) and pallidine (57) from the same part (Gan et al., 2008).

Another study, Chou et al. (2005) was successfully identified a new aporphinoid alkaloid, named as linderaline (58), along with eight known isoquinoline alkaloids, identified as pallidine (57), protosinomenine (59), laudanosoline 3',4'-dimethyl ether (60), boldine (52), norisoboldine (61), norboldine (51), pronuciferine (56), and reticulline (55) from the ethanol extract of the dried roots part. In addition, Kuo et al. (2014) managed to isolate a new $\beta$-carboline alkaloid, linderaggrine A (63) from the roots part of L. aggregata. $\beta$-Carboline alkaloids are a prevalent class of biologically active natural products and this is the first report from this plant. Recently, Yang et al. (2020) were successfully 
characterized three new benzylisoquinoline alkaloids, (1'S)-12'-hydroxyl-linderegatine (71), (1S)-5'-O-phydroxybenzoyl norreticuline (72), and $\left(1 R, 1^{\prime} R\right)$ 11,11'-biscoclaurine (73), along with eighteen known compounds.

\section{Flavonoids}

Nine flavonoids (85-93) have been isolated from the leaves of L. aggregata. The chemical structures are shown in Figure No. 4. Xiao et al. (2011) successfully characterized eight known flavonoids, identified as quercetin (85), quercetin-3-O- $\alpha$-Darabinofuranoside (86), quercetin-3-O- $\alpha$-Dglucopyranoside (87), quercetin-3-O-Lrhamnopyranoside (88), kaempferol (90), kaempferol-3-O-L-rhamnoside (91), kaempferol-3-OD-glucopyranoside (92), and dihydrokaempferol-3O-L-rhamnoside (93). Compounds (91-93) were isolated for the first time from this species. Meanwhile, quercitrin (89) and their pharmacokinetics studies have been described by $\mathrm{Xu}$ et al. (2017).

\section{Miscellaneous compounds}

In addition to the above-mentioned phytochemicals, some other constituents such as procyanidins (94-96), lignans (97-99), benzenoids (100-101), butenolide (102), and phenolics (103-112) were also identified from the leaves and roots of $L$. aggregata. The chemical structures are shown in Figure No. 5. Ma et al. (2015) managed to isolate two new benzenoids, identified as linderagatin A and B (100-101), together with three known lignans, $\quad r e l-(2 \alpha, 3 \beta)-7-\mathrm{O}-$ methylcedrusin (97), (-)-lyoniresinol (98), and evofolin B (99) from the roots part.

Additionally, the authors also managed to characterize ten known phenolic compounds, which were identified as 3-hydroxy-1-(4-hydroxyphenyl)propan-1-one (103), $p$-hydroxybenzoic acid (104), 4hydroxy-3-methoxy acetophenone (105), methyl 3,5dimethoxy-4-hydroxybenzoate (106), vanillic acid (107), tyrosol (108), 2-(4-hydroxy-3methoxyphenyl)-ethanol (109), 2-(4-hydroxy-3,5dimethoxyphenol)-ethanol (110), 2,6-dimethoxy- $p$ benzoquinone (111), and 6'-O-vanilloyltachioside (112). Meanwhile, Lin et al. (2007) were successfully isolated a new secobutanolide, secoaggregatalactone A (102) from the leaves part. Moreover, three procyanidins were reported by Zhang et al. (2003), characterized as procyanidin B1 (94), cinnamtanin B1 (95), and cinnamtannin B2 (96).

\section{Essential oils}

Three studies have been reported on the essential oil of $L$. aggregata. Analysis of the root tubers oil of $L$. aggregata led to the identification of $\alpha$-longifolene $(15.13 \%)$, bornyl acetate (11.49\%), and $\alpha$-eudesmol (9.14\%) as the major components (Du et al., 2003). In another study, the leaves oil-rich of sesquithuriferol (35.90\%), 14-oxy- $\alpha$-muurolene $(16.45 \%)$ and 1,8-cineole (5.34\%) (Fu et al., 2009). Nevertheless, lindene (19.21\%), linderene (16.83\%), bornyl acetate $(8.26 \%)$ and linderene acetate $(8.17 \%)$ were main constituents of the essential oil of $L$. aggregata roots from Jiangxi Province while that from Fujian Province contained $\beta$-phellandrene $(16.23 \%)$ followed by lindene $(14.90 \%)$, linderene $(12.83 \%)$, and linderene acetate $(9.29 \%)$ (Wu et al., 2010). The above findings suggested that the essential oil content of L. aggregata and its composition showed considerable variations and maybe due to plant origin, ecological and climatic conditions as well as storage duration of medicinal herbs.

\section{Biological activities}

The literature study reveals the need for a thorough investigation of the pharmacological characteristics of the extracts and isolated compounds from $L$. aggregata. The biological activities including antihyperlipidemic, anti-inflammatory, cytotoxicity, insecticidal, antiulcer, hepatoprotective, gastrointestinal, and mutagenicity have been reported in some works.

Urox is an herbal formulation containing concentrated extracts of L. aggregata root, Crataeva nurvala stem bark, and Equisetum arvense stem, have well established traditional uses and reported safe for human consumption (Deshpande et al., 1982). Besides, Schoendorfer et al. (2018) demonstrated viability of this herbal combination to serve as an effective treatment, with minimal side-effects, based on results of the treatment of symptoms of overactive bladder and urinary incontinence.

In addition, the extracts have been used traditionally to treat some types of ailments have not been investigated for their biological activities at all. Thus, this is an opportunity to find new pharmacological properties from this species, not to mention promising sources for drugs. Furthermore, their toxicity has not been studied. The information on the qualification of the extracts is very important to be applied as drugs. 
<smiles>C=C1C2C[C@H]2[C@@]2(C)CC3OC(=O)C(C)=C3[C@@H](O)[C@]12C</smiles><smiles>C=C1C2C[C@H]2C2(C)Cc3oc([C@@H](C)c4cc5c(o4)C[C@@]4(C)[C@H]6C[C@H]6C(=C)[C@H]5[C@H]4O)c(C)c3[C@H](O)[C@H]12</smiles>

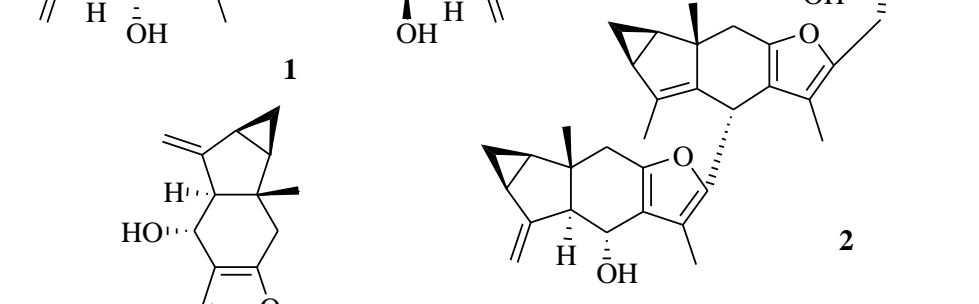
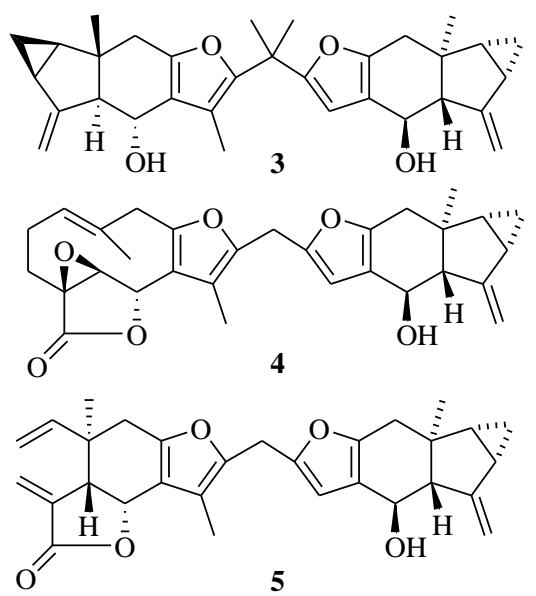
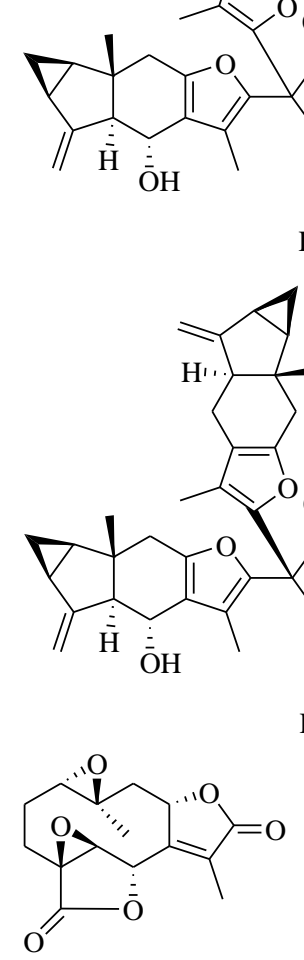

12

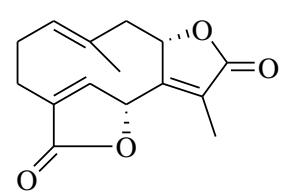

13

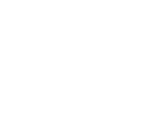

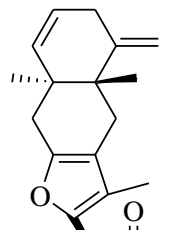
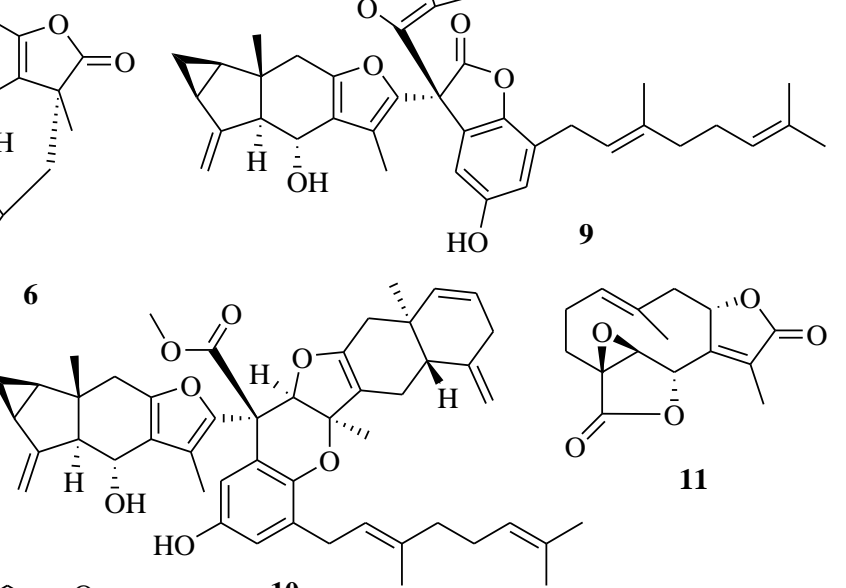

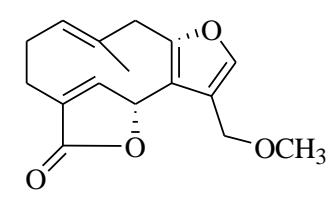

14

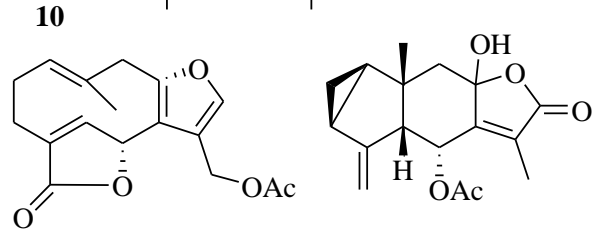

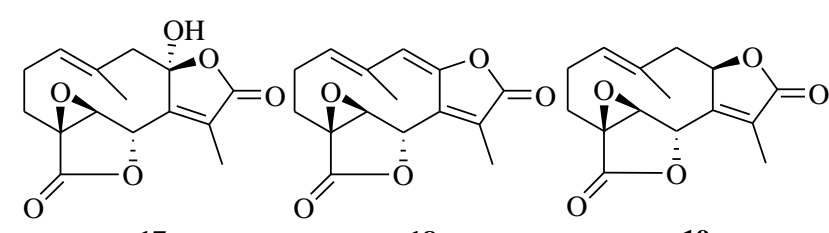

17<smiles>CC1=C[C@H](CCl)C(C)(C)[C@H](O)CC12OC(=O)C(C)=C2C</smiles>

23
18

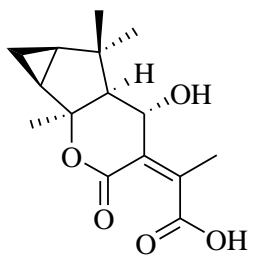

24

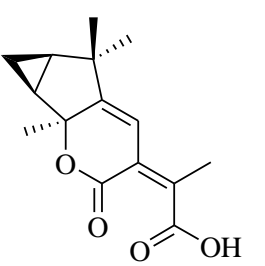

25

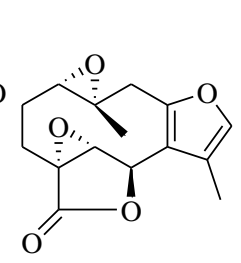

20 is<smiles>C=C1CCC(O)C2CCCC(O)C12</smiles>

21<smiles>C=C1CCC2C(=C)CCC3C(=C)CCC1C(=O)OC23</smiles>

Figure No. 2

Chemical structures of sesquiterpenoids

Boletín Latinoamericano y del Caribe de Plantas Medicinales y Aromáticas/534 
<smiles>CC1=CC[C@@H](O)[C@]2(C)CC[C@H](C(C)(C)O)C[C@H]12</smiles>

28<smiles>C=C1CC=C[C@]2(C)C[C@]3(O)OC(=O)C(C)=C3CC12</smiles>

29<smiles>C=C1CC=C[C@]2(C)C=C3OC(=O)C(C)=C3CC12</smiles>

30<smiles>C=C1C2=C(C)C(=O)O[C@]3(O)C[C@@]4(C)C[C@@H](CC14)O[C@@H]23</smiles>

31<smiles>C=C[C@]1(C)C[C@]2(O)OC(=O)C(C)=C2C[C@H]1C(=C)C</smiles>

32

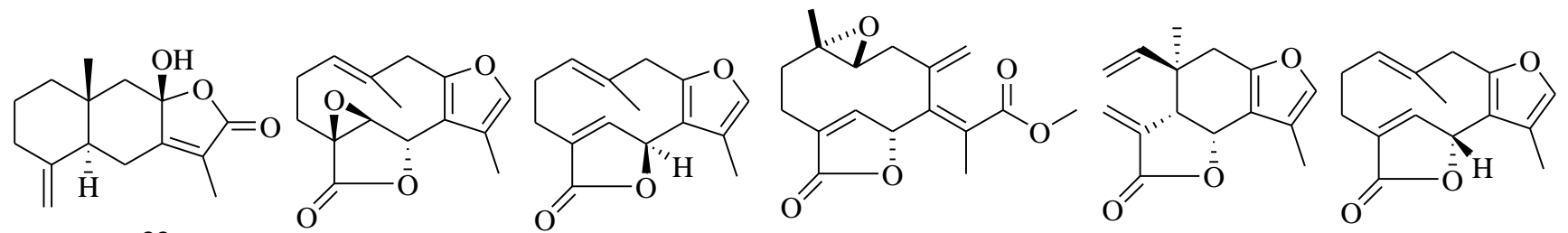<smiles>C=C1CC=C[C@]2(C)C[C@]3(O)OC(=O)C(C)C3=CC12</smiles>

39<smiles>COC(=O)C1=C(OC)C(=O)C2(/C=C/c3ccccc3)OC12OC</smiles>

34

35

37
38<smiles>C=C(CC1=C(OC)CC(OC)=C1OC)OC</smiles><smiles>COC1=C[C@H](c2ccccc2)C2(C(=O)C(OC)C(OC)C2=O)[C@H](c2ccccc2)C1C=C1C(=O)C(OC)=C(OC)C1=O</smiles><smiles>COC1=C[C@H](c2ccccc2)[C@@]2(C(=O)C(OC)=C(OC)C(OC)=C2OC)C(OC)=C[C@@H](c2ccccc2)C12C(=O)C(OC)=C(OC)C2=O</smiles>

43<smiles>[R]c1c(OC)c(=O)oc(/C=C/c2ccccc2)cc1=O</smiles>

$44 \mathrm{R}=\mathrm{H} 45 \mathrm{R}=\mathrm{OCH}_{3}$

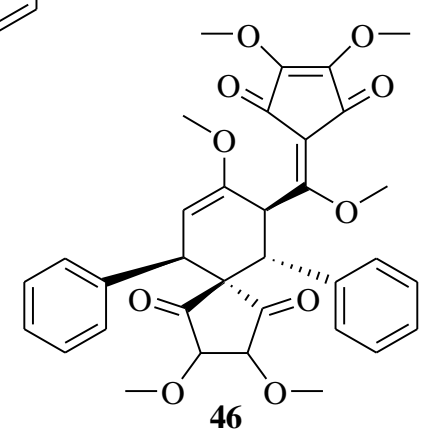<smiles>COC1=C(OC)C(=O)C(=C(OC)[C@H]2C(=O)C[C@@H](c3ccccc3)C3(C(=O)C(OC)C(OC)C3=O)[C@@H]2c2ccccc2)C1=O</smiles><smiles>[R]C1=C(OC)C(=O)C(=C(C=Cc2ccccc2)OC)C1=O</smiles>

Figure No. 2 (continue)

Chemical structures of sesquiterpenoids 
<smiles>[R]c1cc2c3c(c1[R])-c1c(cc([R])c(OC)c1[R])C[C@H]3N([R])CC2</smiles>

$50 \mathrm{R}_{1}=\mathrm{COCH}_{3} ; \mathrm{R}_{2}=\mathrm{OH} ; \mathrm{R}_{3}=\mathrm{OCH}_{3} ; \mathrm{R}_{4}=\mathrm{R}_{5}=\mathrm{H}$

$51 \mathrm{R}_{1}=\mathrm{R}_{4}=\mathrm{R}_{5}=\mathrm{H} ; \mathrm{R}_{2}=\mathrm{OH} ; \mathrm{R}_{3}=\mathrm{OCH}_{3}$

$\mathbf{5 2} \mathrm{R}_{1}=\mathrm{CH}_{3} ; \mathrm{R}_{2}=\mathrm{OH} ; \mathrm{R}_{3}=\mathrm{OCH}_{3} ; \mathrm{R}_{4}=\mathrm{R}_{5}=\mathrm{H}$

$53 \mathrm{R}_{1}=\mathrm{R}_{4}=\mathrm{R}_{5}=\mathrm{H} ; \mathrm{R}_{2}=\mathrm{R}_{3}=\mathrm{OCH}_{3}$

$54 \mathrm{R}_{1}=\mathrm{CH}_{3} ; \mathrm{R}_{2}=\mathrm{R}_{3}=\mathrm{OCH}_{3} ; \mathrm{R}_{4}=\mathrm{R}_{5}=\mathrm{H}$

$58 \mathrm{R}_{1}=\mathrm{R}_{5}=\mathrm{H} ; \mathrm{R}_{2}=\mathrm{R}_{3}=\mathrm{OH} ; \mathrm{R}_{4}=\mathrm{OCH}_{3}$

$61 \mathrm{R}_{1}=\mathrm{R}_{4}=\mathrm{R}_{5}=\mathrm{H} ; \mathrm{R}_{2}=\mathrm{OCH}_{3} ; \mathrm{R}_{3}=\mathrm{OH}$

$67 \mathrm{R}_{1}=\mathrm{CH}_{3} ; \mathrm{R}_{2}=\mathrm{OCH}_{3} ; \mathrm{R}_{3}=\mathrm{R}_{5}=\mathrm{OH} ; \mathrm{R}_{4}=\mathrm{H}$

$75 \mathrm{R}_{1}=\mathrm{R}_{4}=\mathrm{H} ; \mathrm{R}_{2}=\mathrm{R}_{3}=\mathrm{OCH}_{2} \mathrm{O} ; \mathrm{R}_{5}=\mathrm{OH}$

$76 \mathrm{R}_{1}=\mathrm{R}_{4}=\mathrm{H} ; \mathrm{R}_{2}=\mathrm{R}_{5}=\mathrm{OH} ; \mathrm{R}_{3}=\mathrm{OCH}_{3}$<smiles>Cc1ccc2[nH]c3c(C(=O)c4ccc(O)cc4)nccc3c2c1</smiles>

63<smiles>COc1cc2c(cc1O)C(C(=O)c1ccc(Oc3cc(C[C@@H]4NCCc5cc(OC)c(O)cc54)ccc3O)cc1)=NCC2</smiles>

71<smiles>CCN1CCc2cc(O)c(O)cc2C1Cc1ccc(OC)c(O)c1</smiles><smiles>[R]c1cc2c(cc1[R])-c1c([R3])c([R4])cc3c1C(C2)N(C)CC3</smiles>

$79 \mathrm{R}_{1}=\mathrm{R}_{4}=\mathrm{OH} ; \mathrm{R}_{2}=\mathrm{R}_{3}=\mathrm{OCH}_{3}$ $80 \mathrm{R}_{1}=\mathrm{OH} ; \mathrm{R}_{2}=\mathrm{R}_{3}=\mathrm{R}_{4}=\mathrm{OCH}_{3}$<smiles>C=C(/C=C/O)C(C)NC</smiles><smiles>[R4]c1cc(CC2c3c(cc([R])c([R])c3[R])CCN2[R])cc([R4])c1[R5]</smiles>

$55 \mathrm{R}_{1}=\mathrm{CH}_{3} ; \mathrm{R}_{2}=\mathrm{R}_{5}=\mathrm{OCH}_{3} ; \mathrm{R}_{3}=\mathrm{R}_{4}=\mathrm{OH} ; \mathrm{R}_{6}=\mathrm{R}_{7}=\mathrm{H}$ $59 \mathrm{R}_{1}=\mathrm{CH}_{3} ; \mathrm{R}_{2}=\mathrm{R}_{6}=\mathrm{OH} ; \mathrm{R}_{3}=\mathrm{R}_{5}=\mathrm{OCH}_{3} ; \mathrm{R}_{4}=\mathrm{R}_{7}=\mathrm{H}$ $60 \mathrm{R}_{1}=\mathrm{R}_{4}=\mathrm{R}_{7}=\mathrm{H} ; \mathrm{R}_{2}=\mathrm{R}_{6}=\mathrm{OH} ; \mathrm{R}_{3}=\mathrm{R}_{5}=\mathrm{OCH}_{3}$ $70 \mathrm{R}_{1}=\mathrm{R}_{4}=\mathrm{R}_{6}=\mathrm{R}_{7}=\mathrm{H} ; \mathrm{R}_{2}=\mathrm{OCH}_{3} ; \mathrm{R}_{3}=\mathrm{R}_{5}=\mathrm{OH}$ $77 \mathrm{R}_{1}=\mathrm{R}_{2}=\mathrm{R}_{4}=\mathrm{R}_{6}=\mathrm{R}_{7}=\mathrm{H} ; \mathrm{R}_{3}=\mathrm{OCH}_{3} ; \mathrm{R}_{5}=\mathrm{OH}$<smiles>COc1cc2c3c(c1OC)C1(C=CC(=O)C=C1)C[C@H]3NCC2</smiles>

56

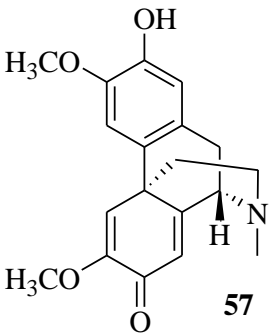<smiles>[R]N1CCc2cc(OC)c(O)cc2C1=O</smiles>

$68 \mathrm{R}=\mathrm{CH} 3$ $69 \mathrm{R}=\mathrm{H}$<smiles>[R]c1cc(CCNC(=O)/C=C/c2ccc(O)c(OC)c2)ccc1O</smiles><smiles>COc1cc2c(cc1O)[C@H](Cc1ccc(OC)c(OC(=O)c3ccc(O)cc3)c1)NCC2</smiles><smiles>COc1cc2c(cc1O)C(Cc1ccc(Oc3ccc(CC4NCCc5cc(OC)c(O)cc54)cc3OC)cc1)NCC2</smiles><smiles>COc1cc2c(cc1O)C(Cc1ccc(Oc3cc(C)ccc3O)cc1)NCC2</smiles>

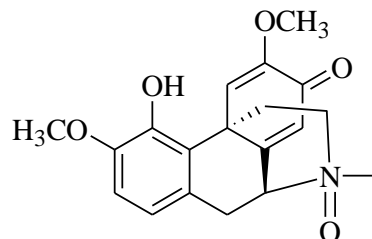

81<smiles>COc1cc2c(cc1O)[C@H](Cc1ccc(O)c(-c3cc(C[C@@H]4NCCC[C@H]4C)ccc3O)c1)NCC2</smiles>

Figure No. 3

Chemical structures of amides and alkaloids 
<smiles>[R]c1c(-c2ccc(O)c(O)c2)oc2cc(O)cc(O)c2c1=O</smiles>

$85 \mathrm{R}=\mathrm{H}$

$86 \mathrm{R}=$ arabinofuranosyl

$87 \mathrm{R}=$ glucopyranosyl

$\mathbf{8 8} \mathrm{R}=$ rhamnopyranosyl

$89 \mathrm{R}=$ rhamnosyl<smiles>[R]Oc1c(-c2ccc(O)cc2)oc2cc(O)cc(O)c2c1=O</smiles>

$90 \mathrm{R}=\mathrm{H}$

$91 \mathrm{R}=$ rhamnosyl

$92 \mathrm{R}$ = glucopyranosyl<smiles>[R]Oc1c(-c2ccc(O)cc2)oc2cc(O)cc(O)c2c1=O</smiles>

$93 \mathrm{R}=$ rhamnosyl

\section{Figure No. 4 \\ Chemical structures of flavonoids}

\section{Antihyperlipidemic}

The aqueous leaves extract of $L$. aggregata showed significantly reduced serum triglyceride (TG), alanine aminotransferase level (ALT), but elevated faecal TG in normal mice. It also remarkably lowered serum total cholesterol (TC), TG, low-density lipoprotein (LDL), N-HDL, ALT, hepatic lipid/glucose (GLU), apolipoprotein B (APOB), hepatic GLU and increased serum high-density lipoprotein (HDL), apolipoprotein A1 (APOA-I), faecal TG levels in hypercholesterolemic (HCL) mice. These results revealed that the extract treatment regulated the disorders of the serum lipid and liver function, reduced hepatic GLU contents both in normal and HCL mice (Zhu et al., 1998; Wang et al., 2020).

\section{Anti-inflammatory}

Aggreganoid A (1) was reported to inhibit the TGF- $\beta$ induced Smad2 protein phosphorylation in a dosedependent manner in A549 cells, and suggested to have potential as TGF- $\beta$ inhibitor. However, no significant activity of aggreganoids A-F (1-6) was reported against A549 and SH-SY5Y cell lines (Liu et al., 2009a). Meanwhile, linderaspirone A (42) was found markedly elevated phosphorylation of InsR, Akt, and GSK-3 $\beta$ under insulin-resistant condition (Wang et al., 2010b). Furthermore, norisoboldine (61) and boldine (52) showed inhibitory activities on nitric oxide production induced by lipopolysaccharide in mouse macrophage RAW 264.7 cells, with $\mathrm{IC}_{50}$ values of 37.8 and $38.7 \mu \mathrm{M}$, respectively (Yang et al., 2020).

\section{Cytotoxicity}

(+)-Norboldine (51) showed weak activity against the mouse lymphocytic leukemia L1210 cell line with
$\mathrm{LC}_{50}$ value $1.1 \times 10^{-4} \mathrm{~mol} / \mathrm{L}$ (Gan et al., 2009b). Secoaggregatalactone A (102) was found to exhibit noticeable cytotoxicity $\left(\mathrm{EC}_{50}\right.$ of $\left.6.61 \mu \mathrm{g} / \mathrm{mL}\right)$ against the human hepatoma cell line (HepG2 cell line). The authors suggested that the compound induced significant apoptotic cell death through the activation of caspase-8, Bid, and caspase-3, leading to cleavage of PARP and causing DNA fragmentation (Lin et al., 2007). In another study, costaricine (74) and laurolitsine (76) showed cytotoxic activities against human colon carcinoma cell line (HCT-116) with $\mathrm{IC}_{50}$ values of 51.4 and $27.1 \mu \mathrm{M}$ against human cancer cell line (HCT-116), respectively (Yang et al., 2020).

\section{Insecticidal}

The essential oil of L. aggregata was found to possess insecticidal activity against two-grain storage insects, Sitophilus zeamais and Tribolium castaneum with $\mathrm{LC}_{50}$ values of 61.65 and $18.47 \mu \mathrm{g} / \mathrm{adult}$, respectively. In addition, the oil showed pronounced fumigant toxicity against Sitophilus zeamais and Tribolium castaneum which gave $\mathrm{LC}_{50}$ values of 23.04 and $14.69 \mathrm{mg} / \mathrm{L}$ air, respectively (Liu et al., 2016).

\section{Antiulcer}

Zhu et al. (1998) were reported the antiulcer action of the extract of the root of $L$. aggregata against the ethanol-induced ulceration model in rats. The extract was found to produce strong local gastric protective effects and mild systemic effects against ethanolinduced ulcer formation. The protective effect may be mediated by endogenous prostaglandins and regulation of the vagus nerve. 
<smiles>Oc1ccc2c(c1)O[C@H](c1ccc(O)c(O)c1)[C@H](O)[C@H]2c1c(O)cc(O)c2c1O[C@H](c1ccc(O)c(O)c1)[C@H](O)C2</smiles>

94

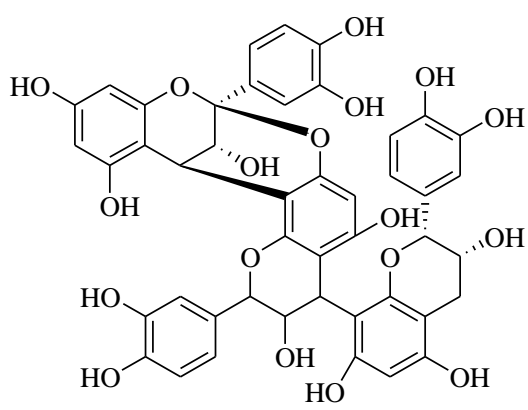

95<smiles>COc1cc([C@@H]2c3c(cc(OC)c(O)c3OC)C[C@@H](CO)C2CO)cc(OC)c1O</smiles>

98<smiles>OCC(CCc1ccc(O)cc1)c1ccc(O)cc1</smiles><smiles>COc1cc(C(=O)C(CO)c2ccc(O)c(OC)c2)ccc1O</smiles><smiles>COc1cc(CCC(CO)c2ccc(O)cc2)ccc1O</smiles>

101<smiles>COc1cc([C@@H]2Oc3c(OC)cc(CCCO)cc3C2CO)ccc1O</smiles>

97<smiles>CCCC/C=C(\C(=O)C(C)=O)C(O)C(C)=O</smiles>

102<smiles>COc1ccc(C(C)=O)cc1O</smiles><smiles>COC(=O)c1cc(OC)c(O)c(OC)c1</smiles>

106<smiles>COc1cc(C(=O)O)ccc1O</smiles>

107<smiles>[R]c1cc(CCO)cc([R])c1O</smiles>

$108 \mathrm{R}_{1}=\mathrm{R}_{2}=\mathrm{H}$ $109 \mathrm{R}_{1}=\mathrm{OCH}_{3} ; \mathrm{R}_{2}=\mathrm{H}$ $110 \mathrm{R}_{1}=\mathrm{R}_{2}=\mathrm{OCH}_{3}$<smiles>[Y13]C1C[C@@H](O)CC(C)(C)C1(O)/C=C/C(C)=O</smiles>

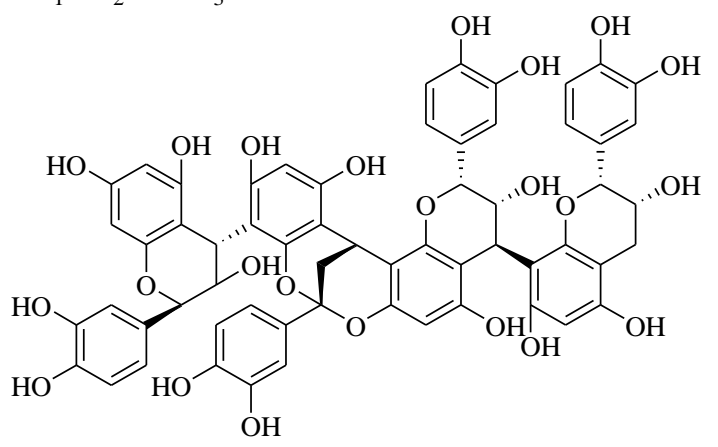

96

Figure No. 5<smiles>COc1cc(OOC2C(O)C(O)C(O)C(O)C2OC(=O)c2ccc(O)c(OC)c2)ccc1O</smiles>

112

\section{Chemical structures of miscellaneous compounds}




\section{Hepatoprotective}

Linderagalactone E (27), linderane (34), hydroxylindestenolide (29), and linderalactone (38) have shown hepatoprotective activity against $\mathrm{H}_{2} \mathrm{O}_{2}-$ induced oxidative damages on $\mathrm{HepG} 2$ cells with $\mathrm{EC}_{50}$ values of $67.5,167.0,42.4$, and $98.0 \mu \mathrm{M}$, respectively (Gan et al., 2009a).

\section{Gastrointestinal}

It has been documented that L. aggregata extract can regulate gastric motility and the essential oil fraction was able to increase the contraction of the intestines, so it can be used as a carminative to treat abdominal distension ( $\mathrm{Li}, 1992)$.

\section{Mutagenicity}

The ethanolic L. aggregata roots extract showed a significant inhibitory mutagenicity effect on the 3amino-1,4-dimethyl-5H-pyrido[4,3-b]-indole (Trp-P1) by the Ames assay (Niikawa et al., 1995).

\section{CONCLUSION}

Until now, significant progress has been witnessed in phytochemistry and pharmacology of L. aggregata.
Thus, some traditional uses have been well supported and clarified by modern pharmacological studies. Moreover, L. aggregata also showed therapeutic potential in the treatment of cardiac, renal, cystic and rheumatic diseases. But present findings are still insufficient that cannot satisfactorily explain some mechanisms of action. More well-designed studies in vitro, especially in vivo, are required to establish links between the traditional uses and bioactivities, discover new skeletons and activity molecules, as well as ensure safety before clinical use. We hope that the information discussed here could make people more aware of L. aggregata and can be beneficial for further research.

\section{ACKNOWLEDGMENTS}

This research was supported by the Ministry of Education (MOE) through the Fundamental Research Grant Scheme for Research Acculturation of Early Career Researchers (FRGSRACER/1/2019/STG01/UPSI/1). The authors also would like to thank the Department of Chemistry, Faculty of Science and Mathematics, UPSI for research facilities.

\section{REFERENCES}

Cao Y, Xuan B, Peng B, Li C, Chai X, Tu P. 2016. The genus Lindera: a source of structurally diverse molecules having pharmacological significance. Phytochem Rev 15: 869 - 906. https://doi.org/10.1007/s11101-015-9432-2

Chen L, Liu B, Deng JJ, Zhang JS, Li W, Ahmed A, Yin S, Tang GH. 2018. Lindera cyclopentenedione intermediates from the roots of Lindera aggregata. RSC Adv 8: 17898 - 17904. https://doi.org/10.1039/C8RA03094D

Cheng XL, Ma SC, Wei F, Wang GL, Xiao XY, Lin RC. 2007. A new sesquiterpene isolated from Lindera aggregata (Sims) Kosterm. Chem Pharm Bull 55: 1390 - 1392. https://doi.org/10.1248/cpb.55.1390

Chou GX, Noerio N, Ma CM, Wang ZT, Hattori M, Xu LS, Xu GJ. 2000. Seven new sesquiterpene lactones from Lindera aggregata. J China Pharm Univ 31: 333 - 340.

Chou GX, Norio N, Ma CM, Wang ZT, Masao H. 2005. Isoquinoline alkaloids from Lindera aggregata. Chinese J Nat Med 3: 272 - 275.

Deshpande P, Sahu M, Kumar P. 1982. Crataeva Nurvala Hook and Forst (Varuna)-the ayurvedic drug of choice in urinary disorders. Indian J Med Res 76: 46 - 53.

Du ZQ, Xia HL, Jiang HX, Zhang BF, Meng F. 2003. Composition of Lindera aggregata essential oil determined by GC-MS. Chinese Trad Herbal Drugs 34: 308 - 310. https://doi.org/10.1080/0972060X.2014.960275

Flora of China Editorial Committee. 2010. Flora of China. Science Press, Beijing, China.

Fu J, Li JM, Chen SY, Yao XL, Wang Q. 2009. Study on chemical constituents of Lindera aggregata essential oil. Chinese Trad Herbal Drugs 40: 112 - 114.

Gan L, Zhao X, Yao W, Wu L, Li L, Zhou C. 2008. A novel bisbenzylisoquinoline alkaloid from Lindera aggregata. J Chem Res 5: 285 - 286. https://doi.org/10.3184/030823408X320674

Gan LS, Zheng YL, Mo JX, Liu X, Li XH, Zhou CX. 2009a. Sesquiterpene lactones from the root tubers of Lindera aggregata. J Nat Prod 72: 1497 - 1501. https://doi.org/10.1021/np900354q

Gan LS, Yao W, Mo JX, Zhou CX. 2009b. Alkaloids from Lindera aggregata. Nat Prod Commun 4: 43 - 46. https://doi.org/10.1177/1934578X0900400111 
Han Z, Zheng Y, Chen N, Luan L, Zhou C, Gan L, Wu Y. 2008. Simultaneous determination of four alkaloids in Lindera aggregata by ultra-high-pressure liquid chromatography-tandem mass spectrometry. J Chromatogr A 1212: 76 - 81. https://doi.org/10.1016/j.chroma.2008.10.017

Hirayama D, Itoh A, Yamakura T. 2004. Implications from seed traps for reproductive success, allocation and cost in a tall tree species Lindera erythrocarpa. Plant Species Biol 19: 185 - 196. https://doi.org/10.1111/j.1442-1984.2004.00114.x

Kuo PC, Li YC, Hwang TL, Ma GH, Yang ML, Lee EJ, Wu TS. 2014. Synthesis and structural characterization of an anti-inflammatory principle purified from Lindera aggregata. Tetrahedron Lett 55: 108 - 110. https://doi.org/10.1016/j.tetlet.2013.10.126

Li GX. 1992. Pharmacology, toxicity and clinic of traditional chinese medicine. Tianjin Science and Technique Translation Publishing House, Tianjin, China.

Li XW. 1984. In Chinese Flora (Zhongguo Zhiwu Zhi). Science Press, Beijing, China.

Lin CT, Chu FH, Chang ST, Chueh PJ, Su YC, Wu KT, Wang SY. 2007. Secoaggregatalactone-A from Lindera aggregata induces apoptosis in human hepatoma Hep G2 cells. Planta Med 73: 1548 - 1553. https://doi.org/10.1055/s-2007-993739

Liu X, Yang J, Fu J, Yao XJ, Wang JR, Liu L, Jiang ZH, Zhu GY. 2009a. Aggreganoids A-F, Carbon-bridged sesquiterpenoid dimers and trimers from Lindera aggregata. Org Lett 21:5753 - 5756. https://doi.org/10.1021/acs.orglett.9b02166

Liu X, Yang J, Yao XJ, Yang X, Fu J, Bai LP, Liu L, Jiang ZH, Zhu GY. 2009b. Linderalides A-D, Disesquiterpenoid-geranylbenzofuranone conjugates from Lindera aggregata. J Org Chem 84: 8242 8247. https://doi.org/10.1021/acs.joc.9b00522

Liu ZL, Chu SS, Jiang CH, Hou J, Liu QZ, Jiang GH. 2016. Composition and insecticidal activity of the essential oil of Lindera aggregata root tubers against Sitophilus zeamais and Tribolium castaneum. J Essent Oil Bear PI 19: 727 - 733. https://doi.org/10.1080/0972060X.2014.960275

Ma GH, Lin CW, Hung HY, Wang SY, Shieh PC, Wu TS. 2015. New benzenoids from the roots of Lindera aggregata. Nat Prod Commun 10: 2131 - 2133. https://doi.org/10.1177/1934578X1501001229

Niikawa M, Wu AF, Sato T, Nagase H, Kito H. 1995. Effects of Chinese medicinal plant extracts on mutagenicity of TRP-P-1. Nat Med 49: 329 - 331.

Qiang Y, Yang ZD, Yang JL, Gao K. 2011. Sesquiterpenoids from the root tubers of Lindera aggregata. Planta Med 77: 1610 - 1616. https://doi.org/10.1055/s-0030-1270922

Salleh WMNHW, Ahmad F, Khong HY, Zulkifli RM. 2015. A review on phytochemistry and pharmacology of the genus Beilschmiedia (Lauraceae). Trop J Pharm Res 14: 2139 - 2150.

Schoendorfer N, Sharp N, Seipel T, Schauss AG, Ahuja KDK. 2018. Urox containing concentrated extracts of Crataeva nurvala stem bark, Equisetum arvense stem and Lindera aggregata root, in the treatment of symptoms of overactive bladder and urinary incontinence: A phase 2, randomised, double-blind placebo controlled trial. BMC Complement Altern Med 18: 42 - 52. https://doi.org/10.1186/s12906-018-2101-4

The Flora of China, 2010. Volume 4. Piperaceae. http://www.efloras.org

The Plant List, 2010. Version 1. http://www.theplantlist.org

Tsui HB. 1987. A study on the system of Lindera. J Grad Sch Chin Acad Sci 25: 167 - 171.

Van der Werff H, Richter HG. 1996. Toward an improved classification of Lauraceae. Ann Miss Bot Gard 83: 409 $-418$.

Wang F, Gao Y, Zhang L, Liu JK. 2010a. Bi-linderone, a highly modified methyl-linderone dimer from Lindera aggregata with activity toward improvement of insulin sensitivity in vitro. Org Lett 12: 2354 - 2357. https://doi.org/10.1021/ol1007247

Wang F, Gao Y, Zhang L, Bai B, Hu YN, Dong ZJ, Zhai QW, Zhu HJ, Liu JK. 2010b. A pair of windmill-shaped enantiomers from Lindera aggregata with activity toward improvement of insulin sensitivity. Org Lett 12: 3196 - 3199. https://doi.org/10.1021/o11011289

Wang J, Wang F, LixiaYuan Wu Y, Peng X, Kai G, Zhu S, Liu Y. 2020. Aqueous extracts of Lindera aggregate (Sims) Kosterm. leaves regulate serum/hepatic lipid and liver function in normal and hypercholesterolemic mice. J Pharmacol Sci 143: 45 - 51. https://doi.org/10.1016/j.jphs.2020.01.009

Wang XH, Kent M, Fang XF. 2007. Evergreen broad-leaved forest in Eastern China: Its ecology and conservation and the importance of resprouting in forest restoration. Forest Ecol Manag 245: 76 - 87.

https://doi.org/10.1016/j.foreco.2007.03.043

Boletín Latinoamericano y del Caribe de Plantas Medicinales y Aromáticas/540 
Wu Y, Zheng Y, Liu X, Han Z, Ren Y, Gan L, Zhou C, Luan L. 2010. Separation and quantitative determination of sesquiterpene lactones in Lindera aggregata (Wu-yao) by ultraperformance LC-MS/MS. J Separat Sci 33: 1072 - 1078. https://doi.org/10.1002/jssc.200900768

Xiao M, Cao N, Fan JJ, Shen Y, Xu Q. 2011. Studies on flavonoids from the leaves of Lindera aggregata. J Chinese Med Mat 34: 62 - 64.

$\mathrm{Xu} \mathrm{B}$, Chen M, Han H, Xu X, Tian J. 2017. Pharmacokinetics and bioavailability of quercitrin in Lindera aggregata leaf extract in rats. Latin Amer J Pharm 36: 495 - 501.

Yang JJ, Chen Y, Guo ML, Chou GX. 2020. Chemical constituents from the roots of Lindera aggregata and their biological activities. J Nat Med 74: 441 - 447.

Zhang CF, Sun QS, Wang ZT, Chou GX. 2001. Studies on constituents of the leaves of Lindera aggregata (Sims) Kosterm. China J Chinese Mat Med 26: 765 - 767.

Zhang CF, Sun QS, Wang ZT, Masao H, Supinya T. 2003. Inhibitory activities of tannins extracted from stem of Lindera aggregata against HIV-1 integrase. Chinese Pharm J 38: 911 - 914.

Zhang CF, Wang ZT. 2000. An advance in the study on medicinal plant of Lindera. J Shenyang Univ Tech 17: $230-234$.

Zhu M, Luk CT, Lew TH. 1998. Cytoprotective effect of Lindera aggregata roots against ethanol-induced acute gastric injury. Pharm Biol 36: 222 - 226. https://doi.org/10.1076/phbi.36.3.222.6349 